\title{
Potential damages, seasonal abundance and distribution of Empoasca terminalis Distant (Homoptera: Cicadellidae) on soybean in South Sulawesi
}

\author{
Potensi kerusakan, kelimpahan populasi dan sebaran \\ Empoasca terminalis Distant (Homoptera: Cicadellidae) pada \\ tanaman kedelai di Sulawesi Selatan \\ Andi Nasruddin ${ }^{*}$, Abdul Fattah ${ }^{2}$, \\ Muhammad Said Baco ${ }^{1}$, Ahwiyah Ekawati Said ${ }^{1}$ \\ ${ }^{1}$ Jurusan Hama dan Penyakit Tumbuhan, Fakultas Pertanian, Universitas Hasanuddin \\ Jalan Perintis Kemeredekaan KM. 10, Makasar 90245 \\ ${ }^{2}$ Balai Pengkajian Teknologi Pertanian Sulawesi Selatan \\ Jalan Perintis Kemerdekaan Km. 17,5, Sudiang PO Box 1234, Makassar 90242
}

(diterima Februari 2014, disetujui April 2014)

\begin{abstract}
Plant damages caused by leafhopper, Empoasca terminalis Distant (Homoptera: Cicadellidae) on soybean were first encountered in 2007 in Makassar, South Sulawesi. The insect has been constantly associated with soybean crops in the province ever since. The purposes of the present study were to (i) evaluate potential yield loss attributable to the leafhopper in an experimental set up, (ii) seasonal abundance of E. terminalis, and (iii) distribution of E. terminalis in all major soybean-producing areas in the province. Potential yield loss due to the leafhopper was assessed in a field experiment using two large plots. One of the plots was kept leafhopper-free by weekly insecticide sprays; and the other plot was left unsprayed to allow leafhopper infestation to occur. Adult abundance was weekly monitored using a sweep net throughout the season. Nymph abundance was determined by direct count on the plant leaves. Leafhopper distribution was assessed through surveys conducted in all major soybean-producing areas in South Sulawesi, from 2009-2013. The results of the study showed that $E$. terminalis caused an average yield loss of $26 \%$ on susceptible crops without insecticide use. First leafhopper infestation in all planting seasons occurred two weeks after the plant emergence. Rainfall negatively correlated with the leafhopper abundance. The leafhopper existed in all major soybean production areas in the province. Therefore, our results confirmed the status of E. terminalis as an important soybean pest in the region. In addition, crops planted early in the dry season could escape from heavy leafhopper infestation.
\end{abstract}

Key words: soybean pest, population fluctuation, plant damages

\footnotetext{
ABSTRAK

Kerusakan tanaman akibat serangan wereng daun, Empoasca terminalis Distant (Homoptera: Cicadellidae), dilaporkan pertama kali tahun 2007 di Sulawesi Selatan. Sejak itu wereng daun tersebut selalu ditemukan menyerang tanaman kedelai. Penelitian ini bertujuan untuk (i) mengevaluasi potensi kehilangan hasil tanaman akibat serangan E. terminalis, (ii) fluktuasi populasi wereng daun, dan (iii) penyebaran $E$. terminalis pada sentra pertanaman kedelai utama di Sulawesi Selatan. Kehilangan hasil akibat wereng daun ditentukan melalui penelitian lapangan dengan dua plot besar. Satu dari plot tersebut dipertahankan agar bebas wereng daun selama musim

*Penulis korespondensi: Andi Nasruddin. Jurusan Hama dan Penyakit Tumbuhan, Fakultas Pertanian, Universitas Hasanuddin,

Jalan Perintis Kemeredekaan KM. 10, Makasaar 90245

Tel: 0411-587100, Faks: 0411-587100,Email: andinasruddin@yahoo.com
} 
tanam dengan penyemprotan insektisida sekali seminggu. Plot yang lain tidak disemprot, sehingga secara bebas terinfestasi oleh wereng daun. Fluktuasi populasi serangga dewasa dimonitor dengan menggunakan jaring serangga, sedangkan populasi nimfa dihitung langsung pada daun. Penyebaran wereng disurvei sejak 2009 hingga 2013 di sentra pertanaman kedelai di Sulawesi Selatan. Hasil penelitian menunjukkan bahwa E. terminalis menyebabkan kehilangan hasil sebesar $26 \%$ pada tanaman rentan tanpa penggunaan insektisida. Infestasi pertama wereng terjadi dua minggu setelah tanaman berkecambah pada pertanaman awal dan akhir musim kemarau. Terdapat korelasi negatif antara curah hujan dan jumlah wereng. E. terminalis ditemukan pada semua sentra pertanaman kedelai di Sulawesi Selatan. Dengan demikian, hasil penelitian ini mempertegas status E. terminalis sebagai hama penting pada tanaman kedelai dan telah menyebar luas pada pertanaman kedelai di Sulawesi Selatan. Di samping itu, tanaman kedelai yang ditanam pada awal musim kemarau dapat terhindar dari serangan wereng yang berat.

Kata kunci: hama kedelai, fluktuasi populasi, kerusakan tanaman

\section{INTRODUCTION}

Empoasca terminalis Distant (Homoptera: Cicadellidae) has been reported as a soybean pest in India (Parsai \& Tiwari 2002). The insect is considered a minor pest on sesame, groundnut (Biswas \& Das 2011), and mungbean (Chhabra et al. 1981). Empoasca terminalis was found with extremely high population of more than 10 individuals per trifoliate, inflicting physiological injury to plants in the form of hopperburn (Nasruddin 2010). The population level was well above the action thresholds of potato leafhopper (Empoasca fabae) on soybean in the USA which vary by plant age. Plants at early vegetative, blooming, and pod developing stages should be treated when there are two leafhoppers per plant, one leafhopper per trifoliate leaf, and two leafhoppers per trifoliate leaf, respectively (Krupke et al. 2013). To the best of our knowledge, this was the first report of soybean crops damaged by E. terminalis in Indonesia. A subsequent survey conducted in 2008 showed that during a drought condition without insecticide applications, the insect can kill up to $24 \%$ of plant population and cause yield loss up to $70 \%$ on susceptible cultivar (Mahameru) (Nasruddin 2010).

Leafhoppers can cause direct and indirect damages to plants. Direct damages include physical injury to plant cells and tissues during the feeding process. Besides that, leafhoppers also produce toxic chemicals injected into plant tissues while they are feeding. The toxin can cause physiological injuries to plants, which are expressed in a symptom called "hopperburn" (Kabrick \& Backus 1990; Eacle \& Backus 1994).
Hopperburn symptoms caused by E. terminalis on soybean first appear as yellow patches starting from the distal end of the leaves. The patches then expand towards the petiole along the leaf margins. This is followed by tissue necrosis also starting from the leaf margin areas. In the advanced damages, crinkling and cupping symptoms on the leaves occur before the whole leaf dries out (Nasruddin 2010). This is similar to hopperburn symptoms on soybean inflicted by potato leafhopper, E. fabae (Hutchins \& Pedigo 1990). In general, leafhoppers can also indirectly damage plants by transmitting plant pathogens such as phytoplasma on potato (Crosslin et al. 2005; Munyaneza et al. 2006) and viruses on rice (Hibino \& Cabunagan 1986; Siwi \& Suzuki 1991).

Currently, soybean growers rely heavily on insecticide use to control E. terminalisr populations. Four insecticides recommended for leafhopper control on other crops i.e. $\lambda$-cyhalothrin, profenofos, deltamethrin and chlorpyrifos at recommended rates, were also effective in suppressing $E$. terminalis populations (Nasruddin 2011). However, dependency solely on insecticides to control E. terminalis should only be used temporarily as an emergency measures. An integrated pest management approach for the insect must be developed to provide effective, efficient, sustainable, and safe control strategies.

An integrated pest management of an insect pest requires thorough and comprehensive understanding of its biology and ecology. Therefore, the objectives of the present study were (i) to determine potential yield loss attributable to $E$. terminalis in an experimental set up; (ii) seasonal abundance of E. terminalis on two varieties with 
different levels of resistance in east and west coasts of South Sulawesi and (iii) distribution of E. terminalis in all major soybean-producing areas in the province.

\section{MATERIALS AND METHODS}

\section{Yield loss}

Yield loss due to E. terminalis was determined in a field study conducted in Sub-district of Simbang, District of Maros. Treatments consisted of two population levels of E. terminalis, very low and high populations. The treatments were arranged in a complete randomized block design with three replications. Each replication consisted of a plot (10 $\mathrm{m} \times 30 \mathrm{~m}$ ) of soybean cv. Mahameru, a susceptible cultivar (Nasruddin 2010), planted on 21 April 2012. Two to three seeds were manually planted in a hole with a planting space of 0.4 between rows and $0.2 \mathrm{~m}$ within a row. All treatment plots were fertilized, weeded, and watered by following the local recommended practices.

To achieve very low populations of $E$. terminalis, the treatment plots were weekly sprayed with insecticides. Four insecticides that had been reported effective against $E$. terminalis were weekly applied, namely: a $\lambda$-cyhalothrin at a rate of $25 \mathrm{~g} \mathrm{A.I} / \mathrm{ha}$ (Polydor 25EC); a profenofos at a rate of $500 \mathrm{~g} \mathrm{A.I./ha} \mathrm{(Biocron} \mathrm{500EC);} \mathrm{a}$ deltamethrin at a rate of $25 \mathrm{~g}$ A.I./ha (Decis 25EC), and a chlorpyrifos at a rate of $20 \mathrm{~g} \mathrm{A.I} / \mathrm{ha}$ (Dursban 200EC) (Nasruddin 2011). The insecticides were applied in rotation to prevent E. terminalis from developing a resistant population against any of the insecticides.

The other treatment was a high population level of E. terminalis. Treatment plots were left unsprayed to allow natural $E$. terminalis infestation to occur throughout the season.

Leafhopper population was weekly monitor using 10-round sweeps in each plot. Samples of E. terminalis were collected in 1-1 plastic bottles, containing a cotton ball saturated with chloroform; then brought to the lab for counting and identification under a dissecting microscope. At mid season, hopperburn intensity was determined by observing 40 plants randomly selected from each plot. Hopperburn level was evaluated using
$0-5$ scales: $0=$ no visible symptom; $1=$ slight cupping of leaf; 2 = slight cupping of leaf with yellowing of leaf margin; 3 = many leaves cupped and yellowed; $4=$ plants stunted and showing leaf scorch; and $5=$ all leaves with severe hopperburn and plants severely stunted. This was based on the scoring used for foliar damage caused by potato leafhopper (E. fabae) on soybean (Schaafsma et al. 1998). At the end of the season, 100 plants that were evenly distributed throughout each plot were randomly selected for harvesting by cutting the stems close to the ground. The plants were then individually bagged and labeled. The pods were dried under the sun until the seed water content was about $18 \%$ before they were weighed to determine dry seed weight per plant.

\section{Seasonal abundance of $E$. terminalis}

To monitor the seasonal abundance of $E$. terminalis, two cultivars with different levels of resistant against E. terminalis: Gepak Kuning (resistant) (Nasruddin et al., unpublished data) and Mahameru (susceptible) (Nasruddin 2010) were planted in Sub-district of Sabbangparu, District of Wajo (east coast) and Sub-district of Simbang, District of Maros (west coast). East and west coasts of South Sulawesi have different rainfall patterns. Rainy and dry seasons occur from May to November and December to April, respectively, in the east coast. While in the west it is just the opposite, rainy and dry season occur from December to April and May to November, respectively. Seeds were planted manually using a sharp wooden pole on 2 January 2013 in the east coast (one planting season) and on 24 April and 8 August 2013 in the west coast (two planting seasons). Each soybean variety was planted in a large plot $(20 \mathrm{~m} \times 50 \mathrm{~m})$ with a planting space of 0.4 between row centers and $0.20 \mathrm{~m}$ within a row. The plots were placed next to each other with a 2-m space of bare land between them. The plots were fertilized, weeded, and watered by following the local recommended practices. However, no pesticides were applied to the plots for the whole season to allow natural infestation of $E$. terminalis to occur.

Each of the large plots (cultivar plots) was divided into six equal size of replication blocks. Adult and nymphal populations were assessed 
weekly starting one week after plant emergence until two weeks before harvest (10 sampling dates). Adult $E$. terminalis were sampled using a standard (38 $\mathrm{cm}$ diameter) sweep net (Munyaneza et al. 2008). In each of the blocks, five round-sweeps were applied and E. terminalis samples were placed in 1-liter plastic jar, containing a cotton ball saturated with chloroform. Empoasca terminalis samples were labeled and then brought to the Laboratory of Insect in Relation to Plant Disease, Faculty of Agriculture, Hasanuddin University. The samples were then sorted, identified, and counted under a dissecting microscope (10-40x). To determine the nymphal population, in each block 10 plants were randomly selected for insect count; and on each plant, the number of nymphs were visually inspected and counted on four upper and middle leaves (Gonzales \& Wyman 1991).

\section{Distribution of $E$. terminalis}

From 2009 to 2013, field surveys were conducted to determine the distribution of $E$. terminalis in all main soybean cultivation sites in the Province of South Sulawesi. Ten districts were surveyed in this study: Jeneponto, Takalar, Gowa, Makassar, Maros, Pangkep, Pinrang, Bone, Soppeng, and Wajo (Figure 5). More than 70\% of all soybean produced in the province comes from those districts. In each district, we used 2-8 farmers' soybean fields, depending on the crop availability at the time of the surveys. Samples of E. terminalis were collected using a sweep net with 10 round-sweeps per field. The insect samples were placed in 1-liter plastic jar, containing a cotton ball, saturated with chloroform. The insects were sorted and counted under a dissecting microscope $(10 \mathrm{x}-40 \mathrm{x})$ in the laboratory.

\section{Data analysis}

Data of hopperburn, population density, and dry seed weight obtained from the insecticide-applied plot and the unsprayed plot were compared using paired-T test. Yield loss due to E. terminalis was calculated using the following equation:

$$
\text { Yield loss }=\frac{\text { YSP - YUP }}{\text { YSP }} \times 100 \% \text {, in which }
$$

Ysp: Yield of sprayed plots; Yup: Yield of unsprayed plots.
Overall average numbers of adults and nymphs found on Gepak Kuning and Mahameru throughout the season in both locations (east and west coasts) were compared using a T-test. Correlation between nymphal and adult populations in each location was assessed using Pearson's correlation coefficient. Pearson's correlation coefficient was also calculated to determine the association between rainfall rates and E. terminalis population levels. Both T-test and correlation analysis were performed using $\log (\mathrm{x}+1)$-transformed count data with the level of significance at $P=0.05$ using a statistical software, Biostat (2009).

\section{RESULTS}

\section{Yield loss}

Weekly insecticide applications were capable of suppressing E. terminalis population to negligible levels. While E. terminalis populations in the unsprayed plot grew freely. All variables measured in the sprayed plot were significantly different from those in the unsprayed plot. Overall average numbers of E. terminalis in the sprayed and unsprayed plots were 4.3 and 112.3 per 10 round-sweeps, respectively $(\mathrm{t}=14.3, \mathrm{P}<0.0001)$. Average hopperburn scores for the sprayed and unsprayed plots were 0.5 and 4.68 , respectively $(\mathrm{t}=4.13, \mathrm{P}<0.05)$. Mean yield per plant was $7.4 \mathrm{~g}$ and $5.5 \mathrm{~g}$ obtained from sprayed and unsprayed plot, respectively. Yield loss due to E. terminalis damage on soybean cv. Mahameru was $1.9 \mathrm{~g}$ per plant or about $26 \%$.

\section{Seasonal abundance of $E$. terminalis}

Overall averages of adults and nymphs were significantly higher on Mahameru than Gepak Kuning $(P<0.01)$ in both locations. This indicated that Mahameru and Gepak Kuning are susceptible and resistant to E. terminalis, respectively.

In all planting seasons of the study, E. terminalis infestations occurred two weeks after the plant emergence (Figure 1-4). There was a general trend of adult leafhopper populations to increase until they reached a peak then declined towards the end of the season. In east coast, adult and nymphal populations reached their peaks 10 and 8 weeks 
after the plant emergence, respectively (Figure 1 and Figure 2).

The average numbers of adults on Mahameru were not significantly different between second planting in the west coast and the east coast. The numbers of adults were 121.3 and 81.3 per 10 round-sweeps in the east and west costs, respectively $(\mathrm{t}=2.68, \mathrm{P}>0.05)$. While, the average numbers of nymphs per plant were 34.7 and 21.1 in the east and west coasts, respectively $(\mathrm{t}=2.27, \mathrm{P}>0.05)$. However, the average numbers of adults and nymphs were significantly lower during the first planting than the second planting in the west coast. The numbers of adults were
32.7 and 81.3 per 10 round-sweeps during the first and the second seasons, respectively $(\mathrm{t}=$ $4.43, \mathrm{P}<0.05)$. Whereas, the numbers of nymphs were 8.71 and 21.1 per plant during the first and the second seasons, respectively $(\mathrm{t}=5.57, \mathrm{P}<$ 0.05 ) (Figure 3 and 4). In the west coast, adult and nymphal populations peaked for the first and second plantings at 12 and 6 weeks after the plant emergence, respectively (Figure 3 and 4).

There was a general trend showing a negative correlation between E. terminalis populations and the rainfall rates, although not all correlations were significantly different (Table 1 and Figure 1 to Figure 4). to Figure 4). On Mahameru, the

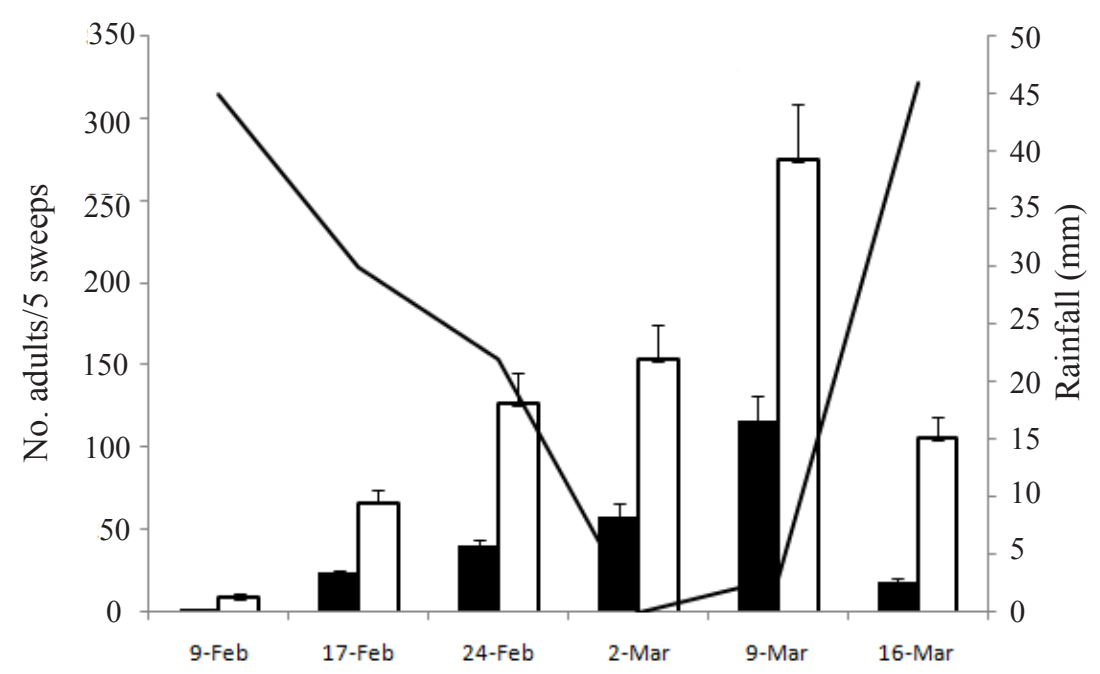

Figure 1. Average numbers of adults of Empoasca terminalis on two cultivars: Gepak Kuning and Mahameru observed weekly for one planting season from 9 February to 16 March 2013 in the east coast of South Sulawesi. Weekly rainfall data provided by the Climatology Station, Maros. Vertical bar = SE. $\square$ : Gepak Kuning; $\square$ : Mahameru; — : Rainfall.

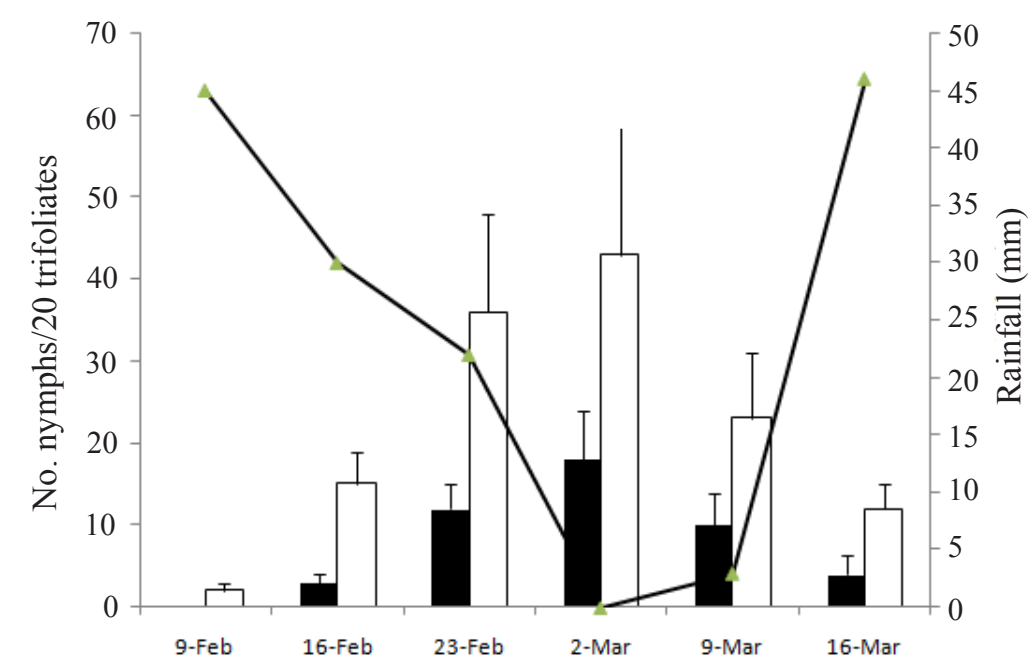

Figure 2. Average numbers of nymphs of Eempoasca terminalis on two cultivars: Gepak Kuning and Mahameru observed weekly for one planting season from 9 February to 16 March 2013 in the east coast of South Sulawesi. Weekly rainfall data provided by the Climatology Station, Maros.

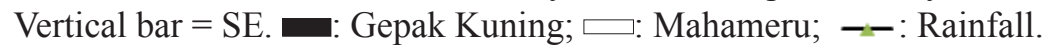




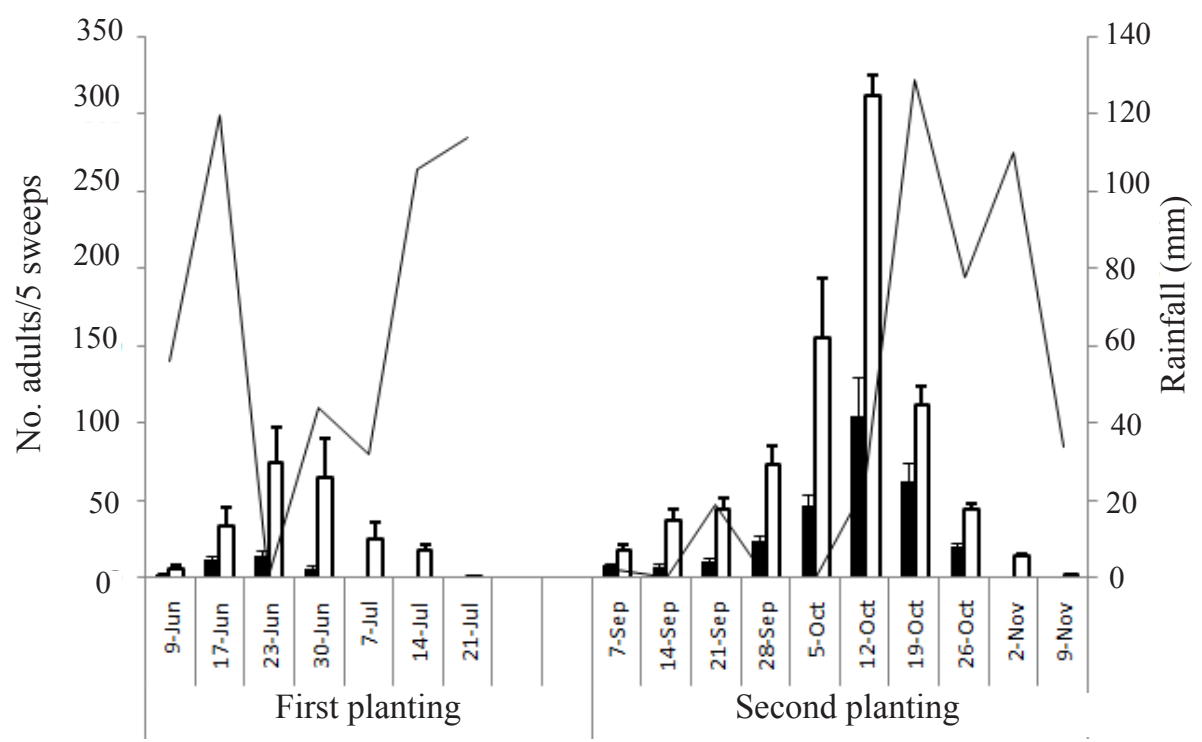

Figure 3. Average numbers of adults of Empoasca terminalis on two cultivars: Gepak Kuning and Mahameru observed weekly for two consecutive planting periods during the dry season in the west coast of South Sulawesi. Weekly rainfall data provided by the Climatology Station, Maros. Vertical bar = SE. Gepak Kuning; $\square$ : Mahameru; ——: Rainfall.

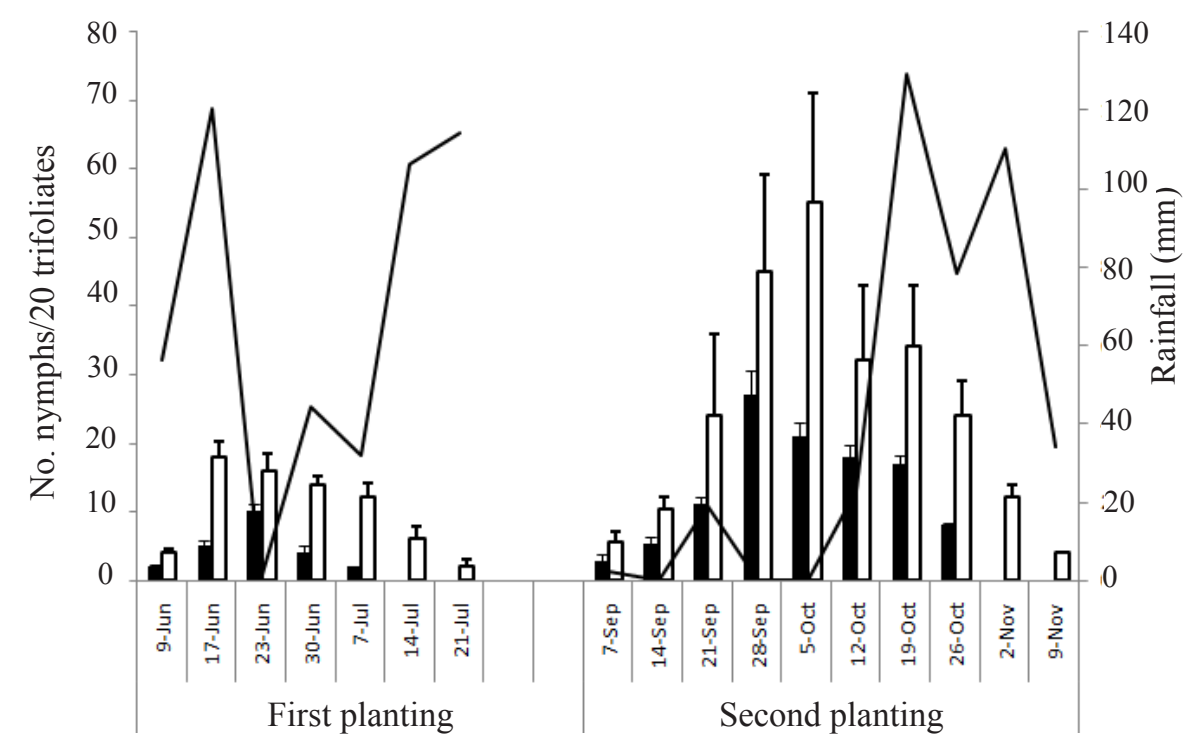

Figure 4. Average numbers of nymphs of Empoasca terminalis on two cultivars: Gepak Kuning and Mahameru observed weekly for two cosecutive planting periods during the dry season in the west coast of South Sulawesi. Weekly rainfall data provided by the Climatology Station, Maros. Vertical bar = SE. $\square$ : Gepak Kuning; $\square$ : Mahameru; __: Rainfall.

number of adults was correlated with the number of nymphs $(\mathrm{r}=0.96, \mathrm{P}<0.05)$. In other words, adult and nymphal population fluctuation patterns were similar. In all planting seasons, only one population peak occurred.

\section{Distribution of $E$. terminalis}

Field surveys conducted from 2009-2013 showed that E. terminalis was found in all major soybean-producing areas, encompassing 10 districts: Jeneponto, Takalar, Gowa, Makassar, Maros, Pangkep, Pinrang, Bone, Soppeng, and 98
Wajo in South Sulawesi (Figure 5). Average numbers of adult $E$. terminalis varied among the districts and the time of the surveys (Table 2).

\section{DISCUSSION}

E. terminalis can be categorized as a new important pest of soybean in South Sulawesi, based on three reasons. First, E. terminalis was always present in the field in each planting season in the province from 2009-2013 (Table 2). Second, 
Table 1. Correlations between leafhopper populations and rainfall rates on soybean cv. Gepak Kuning and Mahameru in east and west coasts of South Sulawesi 2013

\begin{tabular}{lllll}
\hline Location & Cultivar & Growth stage & $\mathrm{r}$ & $\mathrm{P}^{*}$ \\
\hline East Coast & Gepak Kuning & Nymph & -0.86 & 0.02 \\
& & Adult & -0.84 & 0.04 \\
& Mahameru & Nymph & -0.81 & 0.06 \\
& & Adults & -0.78 & 0.06 \\
\hline West Coast & Gepak Kuning & Nymph & -0.61 & 0.15 \\
First Planting & & Adult & -0.30 & 0.34 \\
& \multirow{2}{*}{ Mahameru } & Nymph & -0.35 & 0.38 \\
& & Adults & -0.63 & 0.15 \\
\hline West Coast & Gepak Kuning & Nymph & -0.11 & 0.26 \\
Second Planting & & Adult & -0.11 & 0.28 \\
& \multirow{2}{*}{ Mahameru } & Nymph & -0.21 & 0.31 \\
& & Adults & -0.07 & 0.42 \\
\hline
\end{tabular}

$* \mathrm{P}<0.05$ indicating a significant correlation between population and rainfall.

Table 2. Average numbers of adult leafhoppers (per ten sweeps) caught in the field surveys conducted from 2009 to 2013 in different districts of South Sulawesi Province

\begin{tabular}{llccccc}
\hline $\begin{array}{l}\text { Year of field } \\
\text { survey }\end{array}$ & District & $\begin{array}{c}\text { Sub-districts } \\
\text { sampled }\end{array}$ & $\begin{array}{c}\text { Sub-district } \\
\text { infested }\end{array}$ & Field sampled & Field infested & $\begin{array}{c}\text { No. leafhoppers/ } \\
10 \text { sweeps }\end{array}$ \\
\hline 2009 & Makassar & 2 & 2 & 4 & 4 & 121 \\
& Gowa & 2 & 2 & 5 & 5 & 164 \\
& Makassar & 1 & 1 & 3 & 3 & 74 \\
& Gowa & 2 & 2 & 6 & 6 & 56 \\
& Takalar & 1 & 1 & 4 & 4 & 12 \\
& Jeneponto & 1 & 1 & 2 & 2 & 7 \\
& Pinrang & 2 & 1 & 4 & 2 & 15 \\
& Makassar & 2 & 2 & 4 & 4 & 91 \\
& Gowa & 2 & 2 & 6 & 6 & 112 \\
& Takalar & 2 & 2 & 8 & 7 & 134 \\
& Jeneponto & 1 & 1 & 3 & 3 & 64 \\
& Maros & 1 & 1 & 8 & 8 & 210 \\
& Pangkep & 1 & 1 & 5 & 5 & 189 \\
& Makassar & 1 & 2 & 4 & 4 & 203 \\
& Maros & 2 & 2 & 5 & 5 & 320 \\
& Pangkep & 1 & 1 & 4 & 4 & 276 \\
& Bone & 1 & 1 & 5 & 3 & 6 \\
& Soppeng & 2 & 2 & 6 & 6 & 24 \\
& Wajo & 1 & 1 & 8 & 8 & 36 \\
& Makassar & 1 & 1 & 5 & 5 & 243 \\
& Maros & 2 & 2 & 6 & 6 & 389 \\
& Pangkep & 1 & 1 & 6 & 6 & 258 \\
& Bone & 2 & 1 & 3 & 3 & 14 \\
& Soppeng & 2 & 2 & 4 & 4 & 86 \\
& Wajo & 2 & 2 & 6 & 6 & 114 \\
\hline
\end{tabular}

the E. terminalis population on susceptible crops grew up to the level of way above the economic threshold of E. fabae on soybean. Markel (2007) suggested the economic thresholds of five and nine nymphs per plant for vegetative and early bloom stages of soybean, respectively. While, our present study showed that in all planting times, nymph populations could grow up to more than 60 nymphs per 20 trifoliates. The plants suffered an average yield loss of $26 \%$ which was attributable to $E$. terminalis attack. The last reason is that $E$. terminalis has been found in all major soybean producing areas in the province.

Seasonal abundance study showed that $E$. terminalis first infested crops two weeks after the plant emergence. This result indicated that 


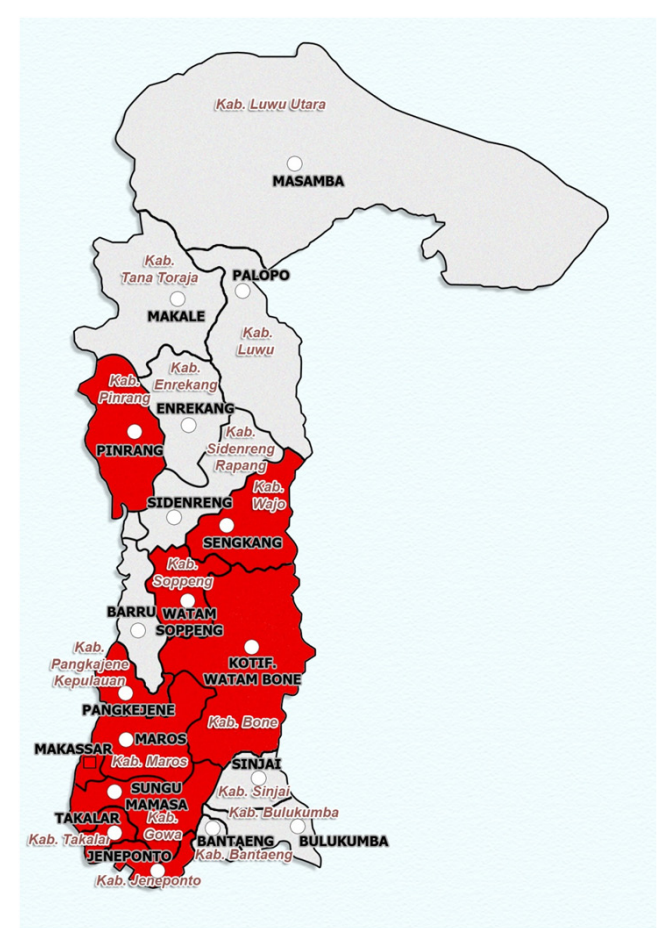

Figure 5. Map of South Sulawesi Province showing the distribution of Empoasca terminalis in major soybean-producing areas. Leafhopper sampling was conducted from 2009-2013. Distribution of E. terminalis ( $\square)$.

E. terminalis infestation related to the crop availability in the fields and was not based on the Julian calendar. Adult and nymphal population fluctuation patterns were similar, suggesting that no new influx of adult immigrants occurred during each season. In all planting seasons, E. terminalis populations peaked only once, indicating that only one complete generation of leafhopper established during each season (Munyaneza et al. 2008).

A heavy rain could knock the leafhopper nymphs down from alfalfa plants (Sutton \& VanKirk 2008). Our results showed that E. terminalis abundance was negatively correlated with the rainfall rate though the correlation was significant only in the east coast. This is probably due to the difference in rainfall patterns in the west and east coasts. In the east coast, the rainfall pattern showed distinct difference between high and low rainfall rates and it had only one bottom; whereas in the west coast, rainfall pattern fluctuated during the seasons. Fluctuating rainfall rates during the season causes a weaker correlation between rainfall and E. terminalis abundance (Varshneya \& Rana 2008). Therefore, the correlation coefficients were greater in the east coast than in the west coast. This finding is in agreement with previous report showing a negative correlation between the relative humidity and jassid-population on okra (Kumawat et al. 2000; Mahmood et al. 2002; Arif et al. 2006; Iqbal et al. 2010). Therefore, the results suggested that planting earlier in the season (April to May) in the west coast could prevent plants from heavy infestation of $E$. terminalis because some precipitations are still expected until midJune in the region.

The study results indicated that Gepak Kuning was resistant to E. terminalis; while Mahameru was susceptible $E$. terminalis. In all planting times, the numbers of adult and nymph E. terminalis on Gepak Kuning were significantly lower than those on Mahameru throughout the planting seasons. Cultivar-based variation in resistance to potato leafhopper ( $E$. fabae) has been reported on other crops, including alfalfa, bean (Ranger \& Hower 2001), and potato (Kaplan et al. 2009). Greater leafhopper mortality and reduced reproduction rate was reported on glandular-haired Medicago spp. and smooth-stem alfalfa varieties were preferred by potato leafhopper (Ranger \& Hower 2002). Trichome excudates entrapped the first instars, causing high mortality at the early stage of the insect life cycle (Ranger \& Hower 2001) and chemical compounds of the exudates repelled the adults from settling (Ranger et al. 2004). Resistance mechanisms in common bean lines against leafhoppers are mainly tolerance and antixenosis. Lines sustaining higher nymphal populations but lower hopperburn scores express a predominantly tolerance defense mechanism The association between lower nymphal population and lower hopperburn injury is an expression of antixenosis (Schaafsma et al. 1998). The current study results suggested that Gepak Kuning resistance mechanism against E. terminalis was predominantly antixenosis.

Survey results showed that E. terminalis has established in all major soybean-producing areas in the province since it was found causing damages on soybean crops in Makassar in 2007 (Nasruddin 2010). Eventhough the numbers of $E$. terminalis adults varied among the survey sites (Table 2), the data could not be used to compare the relative abundance of E. terminalis among the sites. Many variables other than the location 
could affect the leafhopper numbers. Plant age at the time of $E$. terminalis sampling varied among the sites; while plant age affected the number of leafhopper (Sanford 1982). Besides that, bean cultivars react differently to potato leafhoppers (Schaafsma et al. 1998); while different plant cultivars were cultivated in the surveyed fields. In addition, rainfall rate can also affect leafhopper density (Mahmood et al. 2002, Nasruddin 2010).

\section{CONCLUSION}

The study results showed that E. terminalis is an important pest of soybean in South Sulawesi, which potentially causes substantial loss to the crop. Soybean varieties reacted differently to $E$. terminalis infestation. Gepak Kuning is more resistant while Mahameru are susceptible to the insects in all planting seasons in both locations. We also found that planting early in the dry season could prevent the plants from heavy $E$. terminalis infestations. The insect distribution has encompassed all main soybean-producing sites in the province.

\section{ACKNOWLEDGEMENT}

We wish to thank Jumardi for the technical assistance he provided during the course of the study. Rainfall data were provided by the Climatology Station, the Agency for Meteorology, Climatology, and Geophysics, Maros. The study was partly funded by the State Ministry of Research and Technology, Republic of Indonesia, under SINas Incentive Research Scheme No. 123/ UN4.20/PL.09/2013; 27 March 2013.

\section{REFERENCES}

Arif MJ, Gogi MD, Mirza M, Zia K. Hafeez F. 2006. Influence of plant spacing and abiotic factors on population dynamics of sucking insect pests of cotton. Pakistan Journal of Biological Sciences 9:1364-1369. doi: http://dx.doi.org/10.3923/ pjbs. 2006.1364.1369.

Biostat. 2009. Statistical Analysis Program. AnalystSoft, Inc.
Biswas GC, Das GP. 2011. Insect and mite pest diversity in the oilseed crops ecosystems in Bangladesh. Bangladesh Journal of Zoology 39: 235-244.

Chhabra KS, Brar JS, Kooner BS. 1981. Jassid species recorded on green gram, black gram, and red gram in the Punjab. Pulse Crops Newsletter 1: 65 .

Crosslin JM, Munyaneza JE, Jensen A, Hamm PB. 2005. Association of beet leafhopper (Hemiptera: Cicadellidae) with a clover proliferation group phytoplasma in the Columbia Basin of Washington and Oregon. Journal of Economic Entomology 98:279-283. doi: http://dx.doi.org/10.1603/00220493-98.2.279.

Eacle CL. Backus EA. 1994. Time course of anatomical changes to stem vascular tissue of alfalfa, Medicago sativa, from probing injury by the potato leafhopper, Empoasca fabae. Canadian Journal of Botany 73: 288-298. doi: http://dx.doi. org/10.1139/b95-031.

Gonzales AL, Wyman JA. 1991. Effect of varying potato leafhopper (Homoptera: Cicadellidae) population densities on snap bean yield. Journal of Economic Entomology 84:644-649.

Hibino H, Cabunagan PQ. 1986. Rice tungro associated viruses and their relation to host plants and vector leafhopper. Tropical Agricultural Research Series 19:173-182.

Hutchins SH, Pedigo LP. 1990. Phenological disruption and economic consequence on alfalfa regrowth induced by potato leafhopper (Homoptera: Cicadellidae). Journal of Economic Entomology 83:1587-1594.

Iqbal J, Ashfaq M, Mansoor-ul-Hasan; Sagheer M, Nadeem M. 2010. Influence of abiotic factors on population fluctuation of leaf hopper, Amrasca biguttula biguttula (Ishida) on okra. Pakistan Journal of Zoology 42:615-621.

Kabrick LR, Backus EA. 1990. Salivary deposit and plant damage associated with specific probing behaviours of the potato leafhopper, Empoasca fabae, on alfalfa stems. Journal of Entomologia Experimentalis et Applicata 56:287-304. doi: http://dx.doi.org/10.1111/j.1570-7458.1990. tb01407.x.

Kaplan I, Galen L, Dively P, Denno RF. 2009. The costs of anti-herbivore defense traits in agricultural crop plants: a case study involving leafhoppers and trichomes. Journal of Ecological Applications 19:864-872. doi: http://dx.doi. org/10.1890/07-1566.1.

Krupke CH, Obermeyer JL, Bledsoe LW. 2013. Soybean Insect Control Recommendations. Purdue Extension Publication. E-77-W. 
Kumawat RL, Pareek BL, Meena BL. 2000. Seasonal incidence of jassid and whitefly on okra and their correlation with abiotic factors. Annals of Biology 16:167-169.

Markell S. 2007. More potato leafhoppers in dry beans, soybeans, and potatoes. NDSU Crop and Pest Report No. 9, July 5, 2007.

Mahmood T, Hussain SI, Khokhar KM, Jaelani G, Ahmad M. 2002. Population dynamic of leafhopper (Amrasca biguttula biguttula) on brinjal and effects of abiotic factors on its dynamics. Asian Journal of Plant Sciences 1: 402-404.

Munyaneza JE, Crosslin JM, Upton JE. 2006. The beet leafhopper (Hemiptera: Cicadellidae) transmits the Columbia Basin purple top phytoplasma to potato, beet, and weeds. Journal of Economic Entomology 99:268-272. doi: http:// dx.doi.org/10.1603/0022-0493-99.2.268.

Munyaneza JE, Jensen AS, Hamm PB, Upton JE. 2008. Seasonal occurrence and abundance of beet leafhopper in the potato growing region of Washington and Oregon Columbia Basin and Yakima Valley. American Journal of Potato Research 85:77-84. doi: http://dx.doi. org/10.1007/s12230-008-9005-7.

Nasruddin A. 2010. Relative abundance of Empoasca (Distantasca) terminalis (Hemiptera: Cicadellidae), a new pest of soybean (Glycine max) in South Sulawesi Indonesia. In: The Annual Meeting of the Entomological Society of America, (San Diego, California, December 12-15, 2010). San Diego: Entomological Society of America.

Nasruddin A. 2011. Field efficacy of selected insecticides against Empoasca terminalis (Homoptera: Cicadellidae) on soybean. American Journal of Scientific Research 39:115-121.

Parsai SK, Tiwari PN. 2002. Effect of sowing dates, varieties and sulphur doses on incidence of Jassid, Empoasca terminalis Dist. in soybean. Journal of Insect Science 12:8-82.
Ranger CM, Hower AA. 2001. Glandular morphology from a perennial alfalfa clone resistant to the potato leafhopper. Journal of Crop Science 41:1427-1434. doi: http://dx.doi.org/10.2135/ cropsci2001.4151427x.

Ranger CM, Hower AA. 2002. Glandular trichomes on perennial alfalfa affect host-selection behavior of Empoasca fabae. Entomologia Experimentalis et Applicata 105:71-81. doi: http://dx.doi. org/10.1046/j.1570-7458.2002.01035.x.

Ranger CM, Backus EA, Winter REK, Rottinghaus GE, Ellersieck MR, Johnson DW. 2004. Glandular trichome extracts from Medicago sativa deter settling by the potato leafhopper Empoasca fabae. Journal of Chemical Ecology 30:927-43. doi: http://dx.doi.org/10.1023/B:JOEC.0000028459. 45035.90.

Sanford LL. 1982. Effect of plant age on potato leafhopper infestation of resistant and susceptible potato clones. American Potato Journal 59:916. doi: http://dx.doi.org/10.1007/BF02854879.

Schaafsma AW, Cardona C, Kornegay JL, Wylde AM, Michaels TE. 1998. Resistance of common bean lines to the potato leafhopper (Homoptera: Cicadellidae). Journal of Economic Entomology 91:981-986.

Siwi SS, Suzuki Y. 1991. The green leafhopper (Nephotettix spp.): vector of rice tungro virus disease in Southeast Asia, particularly in Indonesia and its management. Indonesian Agricultural Research \& Development Journal 13(1-2):815.

Sutton P, VanKirk J. 2008. IPM for Potato Leafhopper on Alfalfa. NE-IPM Modules, NYS IPM Program. New York: Cornel University.

Varshneya A, Rana KS. 2008. Effect of some abiotic factors on population buildup of Idioscopus clypealis (Lethierry) in western Uttar Pradesh. Journal of Environmental Biology 29:811-812. 